\title{
Uji Efektivitas Ekstrak Kayu Tumbuhan Biau (Psophocarpus sp.) Terhadap Bakteri Salmonella typhi Dan Shigella dysenteriae Penyebab Diare
}

\section{Activity Assay of Plant Biau Wood Extract (Psophocarpus sp.) Against Salmonella typhi and Shigella dysenteriae Causes of Diarrhea}

\author{
Oecy Mardianti ${ }^{1}$, Welly Darwis ${ }^{2}$, Mardhatillah Sariyanti ${ }^{3}$ \\ ${ }^{1}$ Program Studi Kedokteran Fakultas Kedokteran dan IImu Kesehatan, Universitas Bengkulu \\ ${ }^{2}$ Jurusan Biologi Fakultas MIPA Universitas Bengkulu \\ ${ }^{3}$ Program Studi Kedokteran Fakultas Kedokteran dan IImu Kesehatan Universitas Bengkulu \\ Oecy Mardianti ${ }^{1}$, Welly Darwis ${ }^{2}$, Mardhatillah Sariyanti ${ }^{3}$

\begin{abstract}
${ }^{1}$ Medical Study Program, Faculty of Medicine and Health Sciences, University of Bengkulu
${ }^{2}$ Biology Department, Faculty of Mathematics and Natural Science, University of Bengkulu

${ }^{3}$ Medical Study Program, Faculty of Medicine and Health Sciences, University of Bengkulu
\end{abstract}

Corresponding email: mardhatillahs@unib.ac.id

\begin{abstract}
ABSTRAK
Latar Belakang: Angka kematian akibat diare di dunia masih cukup tinggi. Data Dinas Kesehatan Provinsi Bengkulu menunjukkan kasus diare mengalami peningkatan, yaitu sebanyak 50.622 kasus pada tahun 2016 dan 53.348 kasus pada tahun 2017. Salah satu penyebab yang sering ditemukan pada kasus diare adalah infeksi bakteri Salmonella typhi dan Shigella dysenteriae. Pemakaian antibiotik pada kasus diare yang disebabkan bakteri $S$. dysenteriae dan S. typhi sebagian besar telah mengalami resisten. Pada bakteri $S$. dysenteriae ditemukan tingkat resistensi yang tinggi pada antibiotik kotrimoksazol (84\%), tetrasiklin (66\%), ampisilin (56\%) dan kloramfenikol (52\%), sedangkan pada bakteri S. typhi ditemukan resistensi pada antibiotik ampisilin (25\%), kotrimoksazol (18\%) dan masing-masing juga mengalami resistensi pada antibiotik tetrasiklin dan kloramfenikol (15\%). Oleh karena itu, perlunya alternatif lain untuk mengobati diare, salah satunya dengan memanfaatkan tumbuhan obat. Oleh karena itu, penelitian ini bertujuan untuk mendapatkan data ilmiah mengenai efek penggunaan kayu tumbuhan biau sebagai salah satu obat diare yang banyak digunakan oleh masyarakat Suku Serawai di Kecamatan Pino Raya.

Metode: Jenis penelitian ini adalah studi analitik eksperimental laboratorium dan menggunakan metode uji difusi cakram (disk diffusion test). Ekstraksi kayu tumbuhan biau dilakukan dengan metode maserasi menggunakan pelarut etanol 96\% selama 5 hari. Hasil ekstraksi kemudian dilakukan uji fitokimia secara kualitatif dan uji Minimal Inhibitory Concentration (MIC), serta dilanjutkan uji efektivitas. Parameter yang digunakan adalah diameter zona hambat yang terbentuk disekitar kertas cakram, dan kontrol positif yang digunakan adalah larutan antibiotik siprofloksasin.

Hasil: Hasil uji fitokimia menunjukkan bahwa ekstrak kayu tumbuhan Biau mengandung senyawa flavonoid, tannin, dan saponin. Hasil uji MIC menunjukkan bahwa kayu tumbuhan Biau mempunyai aktivitas sebagai antibakteri yang dilanjutkan dengan pengujian efektivitas. Berdasarkan analisis statistik, konsentrasi 55\% merupakan konsentrasi paling efektif untuk bakteri Salmonella typhi dengan diameter zona hambat sebesar $6,20 \mathrm{~mm}$ yang termasuk dalam kategori daya hambat sedang, dan konsentrasi paling efektif untuk bakteri Shigella dysenteriae adalah konsentrasi $70 \%$ dengan diameter zona hambat sebesar $7,66 \mathrm{~mm}$ yang termasuk dalam kategori daya hambat sedang, serta ditandai dengan hasil statistik yang berbeda nyata.
\end{abstract}

Kesimpulan: Ekstrak kayu tumbuhan biau memiliki daya hambat terhadap pertumbuhan bakteri Salmonella typhi dan Shigella dysenteriae.

Kata kunci: Kayu Biau (Psophocarpus sp.), Shigella dysenteriae dan Salmonella typhi. 


\begin{abstract}
Background: Mortality due to diarrhea in the world are still quite high. Bengkulu Provincial Health Office data shows that diarrhea cases have increased, as many as 50,622 cases in 2016 and 53,348 cases in 2017. One of the causes that are often found in cases of diarrhea is bacterial infection of Salmonella typhi and Shigella dysenteriae. The use of antibiotics in cases of diarrhea caused by $S$. dysenteriae and S. typhi bacteria has been largely resistant. In $S$. dysenteriae, high levels of resistance were found in cotrimoxazole antibiotics (84\%), tetracycline $(66 \%)$, ampicillin (56\%) and chloramphenicol (52\%), whereas in S. typhi bacteria found resistance in the antibiotic ampicillin $(25 \%)$, cotrimoxazole (18\%) and each also had resistance to tetracycline and chloramphenicol antibiotics $(15 \%)$. Therefore, the need for other alternatives to treat diarrhea, one of them by using medicinal plants. Therefore, this study aims to obtain scientific data on the effects of the use of Biau plant wood as one of the diarrhea medicines that are widely used by the Serawai Tribe community in Pino Raya District.
\end{abstract}

Methods: This type of research is a laboratory experimental analytical study and used a disk diffusion test method. Biau plant wood was extracted by maceration method using $96 \%$ ethanol for 5 days. Then, the extraction results was tested for qualitative phytochemical and minimal inhibitory concentration (MIC) assay, then effectiveness assay in which both of these assay looked the diameter of inhibition zone formed around the disc paper, and the positive control used ciprofloxacin antibiotic as comparison.

Results: Phytochemical test results were showed that Biau plant wood extract contains flavonoids, tannins, and saponins. MIC test was showed that Biau plant wood has antibacterial activity followed by effectiveness testing. Based on statistical analysis, the concentration of $55 \%$ is the most effective concentration for Salmonella typhi bacteria with inhibition zone diameter of $6.20 \mathrm{~mm}$ which is included in the category of moderate inhibition, and the most effective concentration for Shigella dysenteriae bacteria is $70 \%$ concentration with inhibition zone diameter of $7,66 \mathrm{~mm}$ which is included in the category of moderate inhibition, and marked with statistically significantly different results.

Conclusion: Biau wood extract has inhibitory effect on the growth of Salmonella typhi and Shigella dysenteriae.

Keywords: Biau wood (Psophocarpus sp.), Shigella dysenteriae and Salmonella typhi.

\title{
PENDAHULUAN
}

Angka kematian akibat diare di dunia berkisar 17,5\%-21\% dengan rata-rata penderita diare sebanyak 1,5 juta jiwa setiap tahunnya ${ }^{1}$ Berdasarkan profil kesehatan Indonesia tahun 2016, kasus diare di Indonesia mencapai 6.897.463 kasus dengan kasus yang ditangani sebanyak 2.544.084 kasus $^{2}$. Data dari dinas kesehatan di Provinsi Bengkulu menunjukkan kasus diare mengalami peningkatan, yaitu sebanyak 50.622 kasus pada tahun 2016 dan 53.348 kasus pada tahun $2017^{3}$. Peningkatan angka kejadian diare secara klinis dapat disebabkan oleh beberapa penyebab, seperti infeksi bakteri, infeksi parasit, infeksi virus, malabsorpsi, alergi, keracunan, imunodefisiensi dan sebab lainnya ${ }^{4}$. Salah satu penyebab yang sering ditemukan pada kasus diare adalah infeksi bakteri S. typhi dan S. Dysenteriae ${ }^{5}$.

Pada penanganannya, kasus diare memerlukan penanganan yang cepat dan tepat. Salah satunya adalah dengan menggunakan antibiotik khususnya pada kasus diare yang disebabkan oleh infeksi bakteri. Antibiotik yang sering digunakan adalah golongan flurokuinolon seperti siprofloksasin ${ }^{6}$. Penggunaan antibiotik pada pengobatan harus diperhatikan, karena antibiotik memiliki efek toksik 
yang dapat membahayakan tubuh jika diberikan dalam dosis besar dan dapat menyebabkan resistensi pada pemakaian dalam jangka waktu lama yang tidak terkontrol ${ }^{7}$. Oleh karena itu, perlunya alternatif lain untuk mengobati diare seperti dengan memanfaatkan tumbuhan obat.

Indonesia adalah salah satu negara yang memiliki potensi dalam perkembangan obat-obatan herbal. Data dari departemen perdagangan Indonesia menunjukkan bahwa setiap kepulauan di Indonesia rata-rata memiliki 30.000 spesies tumbuhan yang biasa digunakan masyarakat sebagai perawatan fisik dan kesehatan (pengobatan) ${ }^{8}$. Salah satu tumbuhan yang sering digunakan sebagai obat oleh masyarakat kabupaten Bengkulu Selatan khususnya Suku Serawai di Kecamatan Pino Raya adalah kayu tumbuhan Biau. Menurut survey lapangan yang telah dilakukan oleh peneliti, kayu tumbuhan Biau ini telah dipercaya masyarakat sebagai obat diare dan kebiasaan ini telah berlangsung secara turun-temurun.

Berdasarkan latar belakang di atas dan juga studi literatur yang telah peneliti lakukan bahwa belum terdapat data dan informasi mengenai aktivitas antibakteri ekstrak kayu tumbuhan Biau dalam pengobatan diare, maka peneliti tertarik untuk melakukan penelitian tentang uji efektivitas antibakteri ekstrak kayu tumbuhan Biau terhadap bakteri S. typhi dan S. dysenteriae.

\section{METODE}

Penelitian ini menggunakan studi analitik eksperimental laboratorium yang menggunakan metode uji difusi cakram (disk diffusion test) untuk melihat diameter zona hambat yang terbentuk pada pada bakteri S. typhi dan S. dysenteriae. Lokasi penelitian dilakukan di Laboratorium Basic Science Microbiology Jurusan Biologi FMIPA dengan sampel biakan bakteri S. typhi dengan sertifikat ATCC021131344641131 dan bakteri $S$. dysenteriae dengan sertifikat ATCC-0005010140561211 yang berasal dari Fakultas Kedokteran Universitas Indonesia.

Kayu tumbuhan Biau yang diperoleh dari desa Pasar Pino, kecamatan Pino Raya, kabupaten Bengkulu Selatan diambil sebanyak $6 \mathrm{~kg}$ dan dibersihkan dari kotoran-kotoran, lalu dicuci dengan air yang mengalir hingga bersih. Selanjutnya dipotong-potong menjadi bagian yang kecil lalu di keringanginkan. Setelah itu diblender agar menjadi serbuk kayu (simplisia) tumbuhan Biau yang siap digunakan untuk proses ekstraksi. Proses ekstraksi diawali dengan proses perendaman maserasi, yaitu dilakukan dengan cara mencampurkan bubuk kayu tumbuhan Biau dengan larutan pengekstrak dalam keadaan steril dan dimasukkan ke dalam erlenmeyer steril. Proses ekstraksi dilakukan pada suhu ruang dan diaduk setiap hari selama 5 hari hingga didapatkan endapan (ampas) dan cairan yang 
terpisah. Setelah itu dilakukan penyaringan dengan kertas saring untuk memisahkan filtrat dari ampas sehingga kemudian didapatkan larutan supernatan. Larutan supernatan yang didapat selanjutnya dipekatkan menggunakan rotary evaporator pada suhu $50^{\circ} \mathrm{C}, \pm 1$ minggu hingga didapatkan ekstrak kasar dari kayu tumbuhan Biau. Kemudian ekstrak dimasukkan kedalam waterbath dan oven dengan suhu $40^{\circ} \mathrm{C}-50^{\circ} \mathrm{C}$ selama 1 hari untuk mendapatkan ekstrak kental kayu tumbuhan Biau 9 .

Hasil ekstraksi kemudian dilakukan uji fitokimia secara kualitatif berupa uji flavonoid, uji terpenoid, uji alkaloid, uji tannin, dan uji saponin. Pada pengujian senyawa alkaloid dilakukan penambahan $\mathrm{HCl}$ sebelum ditambahakan pereaksi Meyer, sedangkan pada pengujian tannin ditambahakan $\mathrm{FeCl}_{3}$. Pada uji terpenoid ditambahkan pereaksi kloroform dan $\mathrm{H}_{2} \mathrm{SO}_{4}$ dan untuk uji flavonoid ditambahkan serbuk magnesium dan asam klorida, serta uji saponin ditambahkan akuades setelah dikocok kuat. Hasil positif (+) flavonoid ditandai dengan adanya perubahan warna orange pada larutan ekstrak kayu tumbuhan Biau yang ditambahkan serbuk magnesium dan asam klorida. Uji positif $(+)$ tanin ditandai dengan terbentuknya endapan hijau kehitaman setelah ekstrak ditambahkan beberapa tetes $\mathrm{FeCl}_{3}$ (ferric chloride), sedangkan hasil saponin positif (+) ditunjukkan dengan adanya busa/buih pada ekstrak.

Uji minimum inhibitory concentration (MIC) bertujuan untuk mendapatkan konsentrasi minimum dengan daya hambat kuat, namun jika tidak ada daya hambat kuat, maka diambil konsentrasi $70-80 \%$ dari daya hambat tertinggi. Pada bakteri S. typhi, konsentrasi daya hambat mendekati angka 70-80\% terbaik dikodekan sebagai larutan A4. Kemudian dibuat pengenceran ke konsentrasi lebih kecil dan lebih besar dengan jarak 7,5\% (dikodekan sebagai larutan A2, A3 < A4 < $\mathrm{A} 5, \mathrm{~A} 6$, dan $\mathrm{A} 1=0 \%$, sedangkan untuk bakteri $S$. dysenteriae, konsentrasi zona hambat mendekati angka $70-80 \%$ terbaik dikodekan sebagai larutan B4. Kemudian dibuat juga pengenceran ke konsentrasi lebih kecil dan lebih besar dengan jarak 7,5\% (dikodekan sebagai larutan B2, B3 < B4 < $\mathrm{B} 5, \mathrm{~B} 6$, dan $\mathrm{B} 1=0 \%)$.

Hasil pengukuran zona hambat yang terbentuk di sekitar cakram yang ditetesi berbagai variasi konsentrasi ekstrak kayu tumbuhan Biau ditampilkan dalam bentuk tabel dan grafik. Hasilnya dianalisis dengan uji statistik menggunakan metode Anova dan kemudian dilanjutkan dengan uji Duncan taraf $0,05(5 \%)$ jika terdapat hasil yang beda nyata ${ }^{10}$. 


\section{HASIL}

Kayu tumbuhan Biau diambil dari Desa Pasar Pino, Kecamatan Pino Raya sebanyak 6 kg dengan kriteria kayu berasal dari satu tumbuhan Biau yang merambat pada tumbuhan lain dan berwarna coklat kehitaman. Didapatkan berat kering dari kayu tumbuhan Biau yang telah dihaluskan sebanyak 530 Gram. Hasil penguapan filtrat dengan menggunakan rotary evaporator dan dilanjutkan pemanasan dengan waterbath dan oven pada suhu $40-50^{\circ} \mathrm{C}$ didapatkan ekstrak kental berwarna coklat kehitaman berupa pasta sebanyak 30,7 Gram. Hasil uji fitokimia secara kualitatif menunjukkan bahwa ekstrak kayu tumbuhan Biau mengandung senyawa flavonoid, tannin, dan saponin (Tabel 1).

Tabel 1. Hasil Uji Fitokimia Ekstrak Kayu Tumbuhan Biau

\begin{tabular}{lcc}
\hline \multicolumn{1}{c}{ Nama Sampel } & Parameter & Hasil \\
\hline & Flavonoid & + \\
\cline { 2 - 3 } Ekstrak Kental Kayu & Alkaloid & - \\
\cline { 2 - 3 } Tumbuhan Biau & Tanin & + \\
\cline { 2 - 3 } & Saponin & - \\
\cline { 2 - 3 } & Terpenoid & + \\
\hline
\end{tabular}

\section{A. Hasil Uji Efektivitas Ekstrak Kayu Tumbuhan Biau Terhadap Bakteri Salmonella typhi}

Hasil uji efektivitas ekstrak kayu tumbuhan Biau terhadap bakteri S. typhi dapat dilihat pada

Tabel 2. Berdasarkan tabel tersebut didapatkan bahwa rata-rata zona hambat yang dihasilkan oleh ekstrak kayu tumbuhan Biau terhadap pertumbuhan bakteri S. typhi termasuk ke dalam kategori zona hambat kuat dan sedang. Zona hambat yang diperoleh kemudian dianalisis dengan menggunakan uji statistik. Analisis data pada penelitian ini menggunakan uji non-parametrik yaitu uji Kruskal-Wallis dengan hasil yang didapatkan adalah nilai $p$ value=0,008 $(P<0,05)$. Hal ini menunjukkan adanya kelompok yang memiliki zona hambat berbeda secara bermakna pada hasil pengujian menggunakan Kruskal-Wallis. Setelah itu dilanjutkan analisis statistik dengan uji post hoc Mann-Whitney untuk mengetahui kelompok mana yang memiliki perbedaan bermakna antar konsentrasi.

Tabel 2. Rata-Rata Diameter Zona Hambat Ekstrak Kayu Tumbuhan Biau Terhadap Bakteri Salmonella typhi dan Hasil Analisis post hoc Mann-Whitney

\begin{tabular}{cccccccc}
\hline $\begin{array}{c}\text { Konsentrasi } \\
\begin{array}{c}\text { Rerata Zona } \\
\text { Hambat) }\end{array}\end{array}$ & $\begin{array}{c}\text { Akuades } \\
(0,00)\end{array}$ & $\begin{array}{c}55 \% \\
(6,20)\end{array}$ & $\begin{array}{c}\mathbf{6 2 , 5 \%} \\
(6,36)\end{array}$ & $\begin{array}{c}70 \% \\
(10,15)\end{array}$ & $\begin{array}{c}77,5 \% \\
(11,74)\end{array}$ & $\begin{array}{c}85 \% \\
(10,33)\end{array}$ & P Sig. \\
\hline $\begin{array}{c}\text { Akuades } \\
(0,00)\end{array}$ & - & & & & & & $<0,05$ \\
$55 \%$ & $0,045^{\mathrm{a}}$ & - & & & & & \\
$(6,20)$ & & & & & & &
\end{tabular}




\begin{tabular}{ccccccc}
$\mathbf{6 2 , 5 \%}$ & $0,045^{\mathrm{a}}$ & 0,663 & - & & & \\
$\mathbf{( 6 , 3 6 )}$ & & & & & & \\
$\mathbf{7 0 \%}$ & $0,014^{\mathrm{a}}$ & 0,386 & 0,248 & - & & \\
$(\mathbf{1 0 , 1 5 )}$ & & & & & & \\
$\mathbf{7 7 , 5 \%}$ & $0,014^{\mathrm{a}}$ & 0,386 & 0,564 & 0,773 & - & \\
$\left(\begin{array}{c}\mathbf{1 1 , 7 4 )} \\
\mathbf{8 5 \%}\end{array}\right.$ & & & & & & \\
$\left(\begin{array}{c}\mathbf{1 0 , 3 3 )} \\
\mathbf{K}+\end{array}\right.$ & $0,014^{\mathrm{a}}$ & 0,248 & 0,248 & 1,000 & 1,000 & - \\
$(\mathbf{2 9 , 3 8 )}$ & $0,008^{\mathrm{a}}$ & $0,014^{\mathrm{b}}$ & $0,014^{\mathrm{b}}$ & $0,014^{\mathrm{b}}$ & $0,014^{\mathrm{b}}$ & $0,014^{\mathrm{b}}$ \\
\hline
\end{tabular}

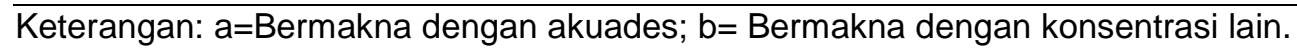

Pada Tabel 2 dapat dilihat bahwa sampel A1E sebagai kontrol negatif tidak menunjukkan adanya zona hambat yang terbentuk. Zona hambat yang terbentuk ditunjukkan oleh sampel dengan sampel A2E (55\%), A3E (62,5\%), A4E (70\%), A5E (77,5\%), A6E (85\%), dan kontrol positif yaitu siprofloksasin. Sampel A2E yaitu pada konsentrasi 55\% memiliki rata-rata zona hambat yang terbentuk adalah 6,20 mm dan masuk ke dalam kategori sedang. Sampel A3E yaitu pada konsentrasi $62,5 \%$ memiliki rata-rata zona hambat yang terbentuk adalah $6,36 \mathrm{~mm}$ dan masuk ke dalam kategori sedang. Sampel A4E yaitu pada konsentrasi $70 \%$ memiliki rata-rata zona hambat yang terbentuk adalah 10,15 mm dan masuk ke dalam kategori kuat. Sampel A5E yaitu pada konsentrasi $77,5 \%$ memiliki rata-rata zona hambat yang terbentuk adalah $11,74 \mathrm{~mm}$ dan masuk ke dalam kategori kuat. Sampel A6E yaitu pada konsentrasi 85\% memiliki rata-rata zona hambat yang terbentuk adalah 10,33 mm dan masuk ke dalam kategori kuat. Kontrol positif yaitu siprofloksasin memiliki rata-rata zona hambat yang terbentuk adalah 29,38 mm dan masuk ke dalam kategori sangat kuat.

Berdasarkan Tabel 2 dapat dilihat bahwa seluruh konsentrasi ekstrak kayu tumbuhan Biau memiliki perbedaan bermakna dengan kontrol negatif (akuades) pada pertumbuhan bakteri $S$. typhi yang ditunjukkan dengan nilai $p$ sig.<0,05, namun tidak menunjukkan perbedaan yang bermakna di setiap perbandingan antara masing-masing konsentrasi ekstrak kayu tumbuhan Biau yang ditunjukkan dengan nilai $p$ sig.>0,05. Hal ini menjelaskan bahwa konsentrasi $55 \%, 62,5 \%, 70 \%, 77,5 \%$, dan $85 \%$ dari ekstrak kayu tumbuhan Biau memiliki efek yang sama dalam kemampuan menghambat pertumbuhan bakteri S. typhi. Sehingga konsentrasi terbaik yang didapatkan adalah konsentrasi 55\%, yaitu konsentrasi terendah yang memiliki daya hambat tertinggi dalam menghambat pertumbuhan bakteri S. typhi. Gambaran zona hambat yang terbentuk pada uji efektivitas ekstrak kayu tumbuhan Biau terhadap pertumbuhan bakteri S. typhi dapat dilihat pada Gambar 1. 

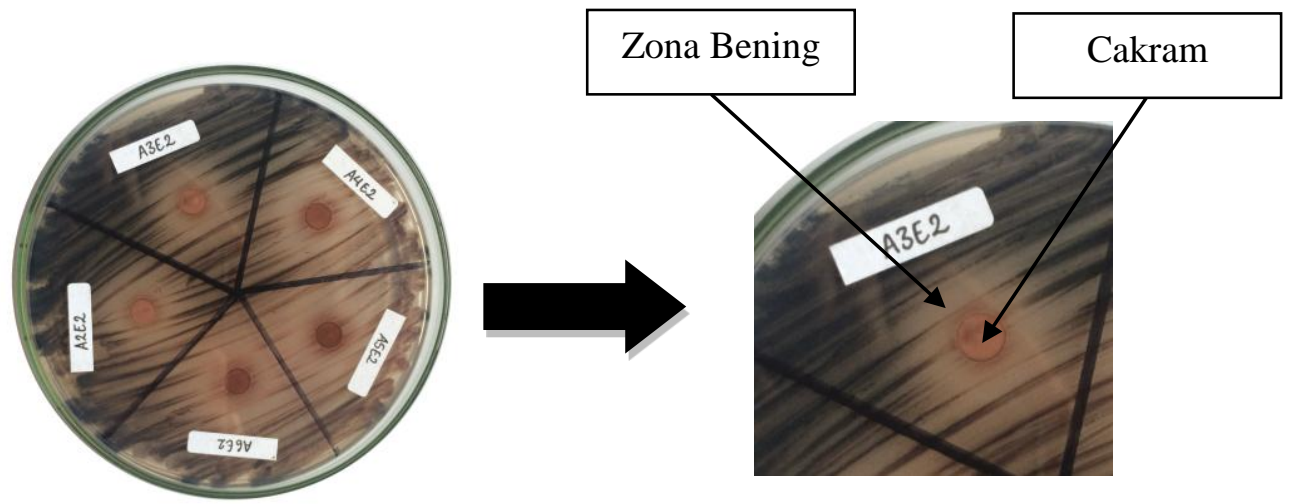

Gambar 1. Zona Hambat yang terbentuk pada Ekstrak Kayu Tumbuhan Biau Terhadap Bakteri Salmonella typhi.

B. Hasil Uji Efektivitas Ekstrak Kayu Tumbuhan Biau Terhadap Bakteri Shigella dysenteriae

Hasil uji efektivitas ekstrak kayu tumbuhan Biau terhadap bakteri $S$. dysenteriae dapat dilihat pada Tabel 3. Berdasarkan tabel tersebut didapatkan bahwa rata-rata zona hambat yang dihasilkan oleh ekstrak kayu tumbuhan Biau terhadap pertumbuhan bakteri $S$. dysenteriae termasuk ke dalam kategori zona hambat sedang. Zona hambat yang diperoleh kemudian dianalisis dengan menggunakan uji statistik. Analisis data pada penelitian ini menggunakan uji non-parametrik yaitu uji Kruskal-Wallis dengan hasil yang didapatkan berupa nilai $p$ value $=0,008 \quad(p<0,05)$. Hal ini menunjukkan adanya kelompok yang memiliki zona hambat berbeda secara bermakna berdasarkan hasil pengujian dengan Kruskal-Wallis. Setelah itu dilanjutkan analisis statistik dengan menggunakan uji post hoc Mann-Whitney untuk mengetahui kelompok mana yang memiliki perbedaan bermakna antar konsentrasi.

Tabel 3. Rata-rata Diameter Zona Hambat Ekstrak Kayu Tumbuhan Biau Terhadap Bakteri Shigella dysenteriae dan Hasil Analisis Post Hoc Mann Whitney

\begin{tabular}{cccccccc}
\hline $\begin{array}{c}\text { Konsentrasi } \\
\text { (Rerata Zona } \\
\text { Hambat) }\end{array}$ & $\begin{array}{c}\text { Akuades } \\
(0,00)\end{array}$ & $\begin{array}{c}55 \% \\
(6,35)\end{array}$ & $\begin{array}{c}\mathbf{6 2 , 5 \%} \\
(6,63)\end{array}$ & $\begin{array}{c}70 \% \\
(7,66)\end{array}$ & $\begin{array}{c}77,5 \% \\
(5,96)\end{array}$ & $\begin{array}{c}\mathbf{8 5} \% \\
(5,36)\end{array}$ & P Sig. \\
\hline $\begin{array}{c}\text { Akuades } \\
(0,00)\end{array}$ & - & & & & & $<0,05$ \\
$\begin{array}{c}\mathbf{5 5 \%} \\
(6,35)\end{array}$ & $0,047^{\mathrm{a}}$ & - & & & & \\
$\mathbf{6 2 , 5 \%}$ & $0,014^{\mathrm{a}}$ & 0,773 & - & & & \\
$(6,63)$ & & & & & & \\
$\mathbf{7 0 \%}$ & $0,014^{\mathrm{a}}$ & 0,083 & $0,043^{\mathrm{b}}$ & - & & \\
$(7,66)$ & & & & & &
\end{tabular}


$77,5 \%$

$(5,96)$

$85 \%$

$(5,36)$

K +

$(37,54)$ $0,008^{a}$
0,309

0,885

0,773

0,386

$0,014^{b}$

0,014

$0,014^{b}$

$0,014^{b} \quad 0,014$

Keterangan: $a=$ Bermakna dengan akuades; $b=$ Bermakna dengan konsentrasi lain.

Pada Tabel 3 dapat dilihat bahwa sampel B1E sebagai kontrol negatif tidak menunjukkan adanya zona hambat yang terbentuk. Zona hambat yang terbentuk ditunjukkan oleh sampel dengan sampel B2E (55\%), B3E (62,5\%), B4E (70\%), B5E (77,5\%), B6E (85\%), dan kontrol positif yaitu siprofloksasin. Sampel B2E yaitu pada konsentrasi 55\% memiliki rata-rata zona hambat yang terbentuk adalah 6,35 mm dan masuk ke dalam kategori sedang. Sampel B3E yaitu pada konsentrasi $62,5 \%$ memiliki rata-rata zona hambat yang terbentuk adalah $6,63 \mathrm{~mm}$ dan masuk ke dalam kategori sedang. Sampel B4E yaitu pada konsentrasi $70 \%$ memiliki rata-rata zona hambat yang terbentuk adalah 7,66 mm dan masuk ke dalam kategori sedang. Sampel B5E yaitu pada konsentrasi $77,5 \%$ memiliki rata-rata zona hambat yang terbentuk adalah 5,96 mm dan masuk ke dalam kategori sedang. Sampel B6E yaitu pada konsentrasi $85 \%$ memiliki rata-rata zona hambat yang terbentuk adalah 5,36 mm dan masuk ke dalam kategori sedang. Kontrol positif yaitu siprofloksasin memiliki rata-rata zona hambat yang terbentuk adalah $37,54 \mathrm{~mm}$ dan masuk ke dalam kategori sangat kuat.

Berdasarkan Tabel 3 juga didapatkan bahwa seluruh konsentrasi ekstrak kayu tumbuhan Biau memiliki perbedaan yang bermakna dengan kontrol negatif (akuades) pada pertumbuhan bakteri $S$. dysenteriae yang ditunjukkan dengan nilai $p$ sig. $<0,05$, dan hanya pada konsentrasi $70 \%$ terhadap konsentrasi $62,5 \%$ yang menunjukkan perbedaan bermakna dengan nilai $p$ sig. $<0,05$ dari semua perbandingan antara masing-masing konsentrasi ekstrak kayu tumbuhan Biau.Hal ini menjelaskan bahwa konsentrasi 55\%, 62,5\%, 77,5\% dan 85\% dari ekstrak kayu tumbuhan Biau memiliki efek yang sama dalam menghambat pertumbuhan bakteri $S$. dysenteriae, kecuali konsentrasi $70 \%$. Sehingga dapat dinyatakan, ekstrak kayu tumbuhan Biau memiliki kemampuan dalam menghambat pertumbuhan bakteri S. dysenteriae dengan konsentrasi terbaik adalah konsentrasi $70 \%$, karena konsentrasi ini memiliki perbedaan yang bermakna terhadap konsentrasi lainnya yang memiliki daya hambat tertinggi pada pertumbuhan bakteri S. dysenteriae. Gambaran zona hambat yang terbentuk pada uji efektivitas terhadap pertumbuhan bakteri S. dysenteriae dapat dilihat pada Gambar 2. 

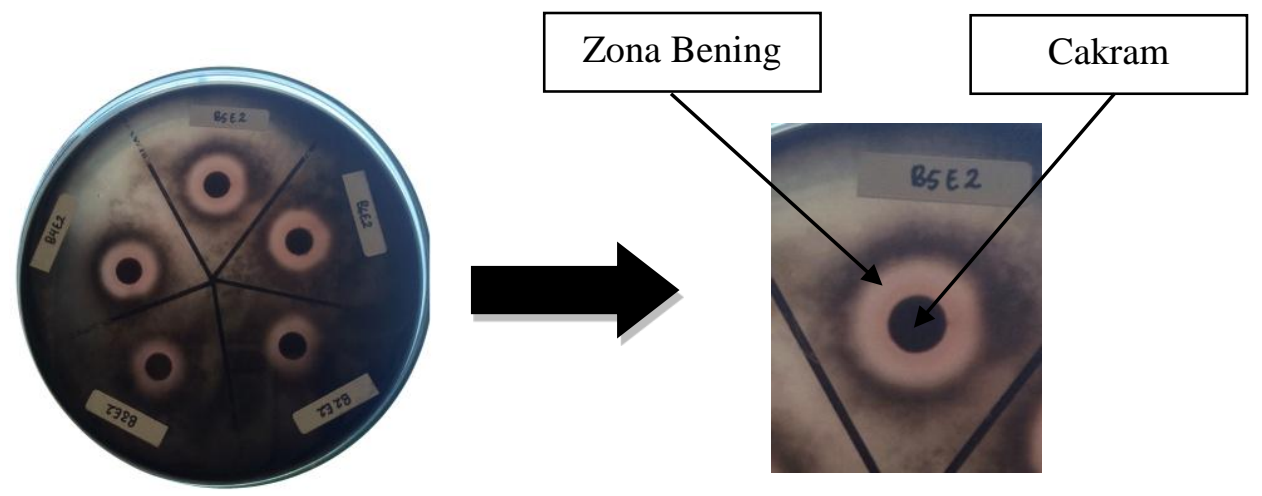

Gambar 2. Zona Hambat yang terbentuk pada Ekstrak Kayu Tumbuhan Biau Terhadap Bakteri Shigella dysenteriae

\section{PEMBAHASAN}

Hasil positif kandungan metabolit sekunder ekstrak kayu tumbuhan Biau menjadi dasar adanya kemampuan daya hambat ekstrak terhadap pertumbuhan bakteri. Senyawa flavonoid memiliki mekanisme kerja berupa mendenaturasi protein sel dan merusak membran sel bakteri ${ }^{11}$. Senyawa saponin bekerja dengan cara merusak membran sitoplasma pada bakteri sehingga menyebabkan kerusakan sel pada bakteri ${ }^{12}$, sedangkan senyawa tanin mempunyai sifat bakteristatik, yaitu menghambat pertumbuhan bakteri dengan cara menginaktivasi adhesin mikroba, enzim dan protein transport pada membran sel bakteri S. typhi dan S. Dysenteriae ${ }^{13}$.

A. Kemampuan Penghambatan Ekstrak Kayu Tumbuhan Biau Terhadap Bakteri Salmonella typhi

Zona hambat yang dihasilkan dari uji efektivitas ekstrak kayu tumbuhan Biau terhadap bakteri S. typhi merupakan zona hambat yang termasuk kedalam kategori sedang dan kuat ${ }^{14}$. Berdasarkan Tabel 2 tersebut dapat dilihat bahwa terdapat hubungan antara besarnya konsentrasi dengan zona hambat yang terbentuk. Zona hambat terbesar terdapat pada sampel A5E yaitu konsentrasi 77,5\% dengan rata-rata zona hambat adalah $11,74 \mathrm{~mm}$, serta zona hambat terkecil terdapat pada sampel A2E yaitu konsentrasi $55 \%$ dengan rata-rata zona hambat adalah $6,20 \mathrm{~mm}$. Bervariasinya diameter zona hambat pada penelitian ini dapat terjadi karena tidak samanya tingkat konsentrasi ekstrak yang diteteskan pada kertas cakram. Penelitian ini sesuai dengan penelitian Rahmah (2017) yang menguji daya hambat filtrat zat metabolit Lactobacillus plantarum terhadap pertumbuhan S. dysenteriae yang didapatkan bahwa semakin tinggi konsentrasi, maka semakin kuat zona hambat yang dihasilkan ${ }^{(18)}$. Selain itu, Loraine (2005) juga menyatakan bahwa semakin besar konsentrasi, maka semakin cepat 
terjadi difusi, sehingga daya antibakteri akan semakin besar dan diameter zona hambat yang dihasilkan semakin luas ${ }^{15}$. Terbentuknya zona hambat pada ekstrak kayu tumbuhan Biau menunjukan bahwa ekstrak tersebut dapat menghambat pertumbuhan bakteri S. typhi.

Pada kontrol positif yang digunakan, yaitu siprofloksasin didapatkan zona hambat yang sangat kuat yaitu 29,38 mm. Diameter zona hambat siprofloksasin lebih besar dibandingkan dengan diameter zona hambat ekstrak, hal ini dikarenakan siprofloksasin bersifat bakterisidal dan merupakan antibiotik spektrum luas golongan florokuinolon dengan mekanisme kerja menghambat DNA girase (topoisomerase II) dan (topoisomerase IV) yang terdapat di dalam bakteri ${ }^{(7)}$.

B. Kemampuan Penghambatan Ekstrak Kayu Tumbuhan Biau Terhadap Bakteri Shigella dysenteriae

Zona hambat yang dihasilkan dari uji efektivitas ekstrak kayu tumbuhan Biau terhadap bakteri S. dysenteriae merupakan zona hambat yang termasuk kedalam kategori sedang ${ }^{14}$. Berdasarkan penelitian yang dilakukan oleh Iriano (2008) hal tersebut dapat disebabkan oleh banyaknya faktor yang berpengaruh terhadap besar zona hambatan yang dihasilkan pada metode difusi antara lain kecepatan difusi, sifat media agar yang digunakan, jumlah organisme yang diinokulasi, kecepatan tumbuh bakteri, konsentrasi bahan kimia, serta kondisi pada saat inkubasi ${ }^{16}$. Tidak adanya zona hambat dengan kategori kuat disebabkan karena $S$. dysenteriae mempunyai struktur antigen yang kompleks, terdapatnya tumpang tindih dalam sifat serologik berbagai spesies dan sebagian dari kuman ini mempunyai antigen $O$,sehingga sulitnya ekstrak untuk menembus bakteri tersebut ${ }^{17}$.

\section{KESIMPULAN DAN SARAN}

Ekstrak kayu tumbuhan Biau berpotensi sebagai antibakteri dalam menghambat pertumbuhan bakteri Salmonella typhi dan Shigella dysenteriae yang ditandai dengan terbentuknya zona hambat yang masuk ke dalam kategori sedang sampai kuat dengan konsentrasi efektif daya hambat masingmasing pertumbuhan kedua bakteri tersebut, yaitu 55\% dan 70\%. Peneliti menyarankan untuk dilakukan penelitian in vitro ulang untuk melihat aktivitas antibakteri ekstrak kayu tumbuhan biau (Psophocarpus sp.) sebagai pengobatan alternatif penyakit diare sebelum dilakukan uji in vivo pada hewan coba dan uji klinik. Selain itu, perlu dilakukan penelitian lanjutan sesuai kebiasaan masyarakat desa Pasar Pino berupa air rebusan kayu tumbuhan biau. 


\section{DAFTAR PUSTAKA}

1. World Health Organization. 2005. Guidelines for the Control of Shigellosis, including Epidemics due to $S$. dysenteriae type 1. hal. 1-70. http://apps.who.int/iris/bitstream/handle/ 10665/43252/9241592330.pdf;jsessionid=1514DF443534E3308F01B871367AC29F?sequenc e=1[Accessed 20 Februari 2018].

2. Kementerian Kesehatan. 2017. Profil Kesehatan Indonesia 2016. Diedit oleh B. Hardhana, Yudianto dan T. Soenardi. Jakarta: Kementerian Kesehatan Indonesia. http://www.depkes. go.id/resources/download/pusdatin/profil-kesehatan-indonesia/Profil-Kesehatan-Indonesia2016.pdf [Accessed 20 Februari 2018].

3. Dinkes Provinsi Bengkulu. 2018. Profil Kesehatan Provinsi Bengkulu Tahun 2017, pp. 1-154: Dinas Kesehatan Provinsi Bengkulu. http://www.depkes.go.id. [Accessed 11 Desember 2018].

4. Kementerian Kesehatan. 2011. Situasi Diare di Indonesia. Jakarta, 2(2), hal. 1-44. http://www.depkes.go.id/resources/download/pusdatin/profil-kesehatan-indonesia/profilkesehatan-indonesia-2011.pdf [Accessed 3 Maret 2018].

5. Gillespie, S., dan Bamford, K. 2012. Medical Microbiology and Infection at a Glance. Fourth Edi. United Kingdom: Wiley-Blackwell.

6. Gidding, S.L., Stevens, A.M., dan Leung, D.T. 2016. Traveler's Diarrhea. Vol 100. Issue 2. USA: Elsevier.

7. Setiabudy. R. 2007. Farmakologi dan Terapi Edisi 5. Jakarta: Departemen Farmakologi dan Terapeutik Fakultas Kedokteran Universitas Indonesia.

8. Departemen Perdagangan RI. 2009. Indonesian Herbal The Traditional Therapy. Trade Research \& Development Agency, hal. 1-5.

9. Sanja, S.D., Sheth, N.R., Patel, N.K., Patel, D., dan Patel, B. 2009. Characterization and Evaluation, of Antioxidant Activity of Portulaca oleracea. Rajkot: B. K Mody Government Pharmacy College.

10. Dahlan, M.S. 2014. Statistik Untuk Kedokteran dan Kesehatan. Seri 1, Edisi 6. Jakarta: Epidemiologi Indonesia.

11. Juliantina, F. 2009. dalam Candrasari, A., Romas, M.A., dan Astuti, O.R. 2012. Uji daya antimikroba ekstrak etanol daun sirih merah (Piper Crocatum Ruiz \& Pav.) terhadap pertumbuhan Staphylococcus aureus Atcc 6538, Eschericia coli Atcc 11229 dan Candida albicans Atcc 10231 secara in vitro. Fakultas Kedokteran Universitas Muhammadiyah Surakarta. https://doi.org/10.23917/biomedika.v4i1.258 [Accessed 7 Juli 2018].

12. Robinson. 2005. Kandungan Organik Tumbuhan Tinggi. Diterjemahkan oleh Kosasih, P. Bandung: ITB.

13. Naim. 2004. dalam Rahmi, A., Cahyanto, T., Sujarwo, T. dan Lestari R.I. 2015. Uji Aktivitas Antibakteri Ekstrak Daun Beluntas (Pluchea indica (L.) Less.) Terhadap Propionibacterium acnes Penyebab Jerawat. Skripsi. Bandung: Fakultas Sains Dan Teknologi Uin Sunan Gunung Djati Bandung.

14. Davis, W.W. dan Stout. T.R. 1971. Disc Plate Methods of Microbiological Antibiotic Assay. hal 659-665.

15. Loraine, V. 2005. Antibiotic in Laboratory Medicine. 5th Edition. London; Williams and Wilkins Co. p 259.

16. Iriano, A. 2008. Efek Antibakteri Infusum Aloe vera terhadap Porphyromonas gingivalis In Vitro (Perbandingan Metode Ekstraksi Maserasi dan Infundasi) Fakultas Kedokteran Gigi Program Studi Pendidikan Dokter Gigi. Skripsi. Jakarta: Universitas Indonesia.

17. Jawetz, Melnick dan Adelberg. 2013. Medical Microbiology. Twenty-Six. Diedit oleh S. A. Morse et al. North America: The McGaw-Hill. 